Benha Veterinary Medical Journal
$\begin{gathered}\text { Official Journal Issued by } \\ \text { Fecterly of } \\ \text { Veterinary Medicine }\end{gathered}$
Journal homepage: https://bvmj.journals.ekb.eg/

Original Paper

\title{
Determination of biogenic amines in hard cheeses by high performance liquid chromatography
}

Madeha A. Hassan ${ }^{1}$, Salah F. Abd El-Aal ${ }^{1}$, Rania M. Kamal ${ }^{1}$, Yasmin A. A. Ahmed ${ }^{1}$, Marionette Z. Nasseif ${ }^{2}$

${ }^{1}$ Department of Food Control, Faculty of Veterinary Medicine Zagazig University, Egypt

${ }^{2}$ Department of Food Hygiene, Animal Health Research Institute, Egypt

\begin{tabular}{|c|c|}
\hline ARTICLE INFO & ABSTRACT \\
\hline $\begin{array}{l}\text { Received 28/01/2020 } \\
\text { Accepted 19/03/2020 } \\
\text { Availa6le On-Line } \\
\text { 18/07/2020 }\end{array}$ & $\begin{array}{l}\text { This study evaluated chemically the quantity of six biogenic amines "histamine, tyramine, } \\
\text { putrescine, cadaverine, tryptamine and phenylethylamine" in forty hard cheese samples } \\
\text { (Cheddar and Ras) ( } 20 \text { of each) sold in retail markets in Zagazig City Sharkia Governorate } \\
\text { using high performance liquid chromatography (HPLC) and correlation with compositional } \\
\text { quantity of cheese ( } \mathrm{pH} \text {, salt } \% \text {, moisture } \% \text { and acidity } \%) \text {. Our results showed the mean values } \\
\text { of } \mathrm{pH} \text {, salt, moisture and acidity were }(5.5 \pm 0.02 \text { and } 4.79 \pm 0.11),(1.53 \pm 0.04 \text { and } 4.42 \pm 0.05 \%) \text {, } \\
(40.45 \pm 0.24 \text { and } 38.64 \pm 0.34 \%) \text { and }(0.84 \pm 0.01 \text { and } 1.70 \pm 0.04 \%) \text { in Cheddar and Ras cheese } \\
\text { samples, respectively. The mean values of total biogenic amines were } 12.65 \pm 2.7 \text { and } 28.95 \pm 4.6 \\
\text { mg/100g in Cheddar and Ras cheese samples, respectively. There was a negative correlation } \\
\text { between (pH value and moisture } \%) \text { and biogenic amines production but the positive } \\
\text { correlation was found between (salt and acidity } \%) \text { and biogenic amines production. Finally, it } \\
\text { was found that all Cheddar and Ras cheese samples were accepted according to maximum } \\
\text { permissible limit of Egyptian organization standard (EOS, 2007) which is 20mg/100g. All } \\
\text { samples were accepted according to maximum permissible limit of Food and Drug } \\
\text { Administration (FDA, 2001) which is } 10 \mathrm{mg} / 100 \mathrm{~g} \text { except } 60 \text { and } 90 \% \text { of Ras cheese samples } \\
\text { are accepted for histamine and putrescine, respectively. On conclusion, optimization and } \\
\text { standardization of milk quality and hygiene during cheeses manufacturing and storage should } \\
\text { be taken for human safety. }\end{array}$ \\
\hline
\end{tabular}

\section{INTRODUCTION}

Cheese is considered the most consumed dairy product in the world as it is considered a good source of calcium, proteins, fatty acids, vitamins and minerals. In addition, the high digestibility of proteins due to proteolytic activity during ripening of cheese. Also, it is considered a suitable food for patients who suffering from diabetes or lactose malabsorption, due to low lactose content (Kayagil, 2006). Biogenic amines (BAs) are low molecular weight nitrogenous basic, organic compo-unds, usually formed by removal of the alpha-carboxyl group (decarboxylation) of corresponding amino acids leading to Biogenic amines formation, e.g., histamine from histidine, tyramine from tyrosine, cadaverine from lysine, tryptamine from tryptophan, putrescine from ornithine and phenylethylamine (PEA) from phenylalanine (Bodmer et al.,1999). BAs levels in cheese influenced by several factors as $\mathrm{pH}$, salt \%, moisture\%, acidity\%, milk pasteurization, level of proteolysis, general hygienic conditions, storage time and temperature, type of cheese and the presence of microorganisms having decarboxylase activity (Lehane and Olley, 2005). Some types of cheeses, like hard cheeses, represent an ideal food for accumulation of BAs due to a longer ripening period (Maintz and Novak, 2007).
Histamine plays an important role in food poisoning incidents due to its action on cardiovascular system as vasodilator and on the central nervous system as neurotransmitter, so high histamine levels lead to migraine, headaches, vertigo, anaphylaxia, hypotension, nausea, vomiting and arrhythmia (Novella et al.,2003 and Ladero et al., 2008). Tyramine is the most frequent biogenic amine found in cheese, reaching levels higher than $1000 \mathrm{mg} / \mathrm{kg}$ (Fernández et al., 2006). Term 'cheese reaction' refers to tyramine intoxication from cheese (Ten Brink et al., 1990). Polyamines (putrescine and cadaverine) may enhance histamine toxicity by inhibiting its catabolism. In addition, they are associated with cancer growth and development by formation of carcinogenic N-nitrosamine (Gerner, 2004 and Moinard et al., 2005).There are several analytical techniques for detection the levels of BAs in various foods, among them HPLC with a detection limit $0.1 \mathrm{mg} / \mathrm{kg}$ so, this method usually applied for official control (EFSA, 2011). There are two reasons for evaluation of BAs content in foods: their toxic effect on human health and using them as quality indicators (ÖNAL, 2007).

The aim of this work was to estimate the BAs in hard cheeses and correlate their levels with $\mathrm{pH}$, salt $\%$, moisture $\%$ and acidity $\%$, then finally comparing our results with EOS (2007) and FDA (2001).

\footnotetext{
* Corresponding author: Yasmin A. A. Ahmed, Department of Food Control, Faculty of Veterinary Medicine Zagazig

University, Egypt
} 


\section{MATERIAL AND METHODS}

\subsection{Collection of samples}

Forty random samples of hard cheeses (Cheddar and Ras) (20 of each) were collected from retail markets in Zagazig city, Sharkia Governorate. Samples were analyzed chemically for estimation of $\mathrm{pH}$, salt $\%$, moisture $\%$ and acidity $\%$. Also examined to quantify their content of BAs "histamine, tyramine, cadaverine, tryptamine, putrescine and phenylethylamine".

\subsection{Chemical analysis:}

Each cheese sample was prepared according to AOAC (2016). Measuring the $\mathrm{pH}$ value by inserting electrical $\mathrm{pH}$ meter (900 NEL brand $\mathrm{pH}$ meter) directly into previously prepared sample. Salt $\%$, moisture $\%$ and acidity $\%$ were determined according to AOAC (2016).

\subsection{Determination of biogenic amines:}

Six BAs including "histamine, tyramine, cadaverine, putrescine, tryptamine and phenylethylamine" were determined in all examined cheese samples in National Research Center in Egypt according to the method adopted by (Moret and Conte, 1996).

\subsubsection{Preparation of Standard solutions:}

The standard solutions of the tested BAs were prepared by adding weighed amount of each amine $(100 \mathrm{mg})$ to a flask of $100 \mathrm{ml}$ volume and dissolving in required amount of distilled water individually.

\subsubsection{Extraction of samples:}

In cheese analysis, two extractions were carried out $(10 \mathrm{~g}$ of each cheese sample was homogenized well and blended with $20 \mathrm{ml}$ of $0.1 \mathrm{M} \mathrm{HCL}$. The extracts were saturated with Sodium chloride and adjusting $\mathrm{pH}$ to (11.5) by automatic titrator. The extraction with $5 \mathrm{ml}$ butanol, a solvent was carried out in a separated funnel with blending and agitation for 30 minutes.

2.3.3. Derivatization:

In a test tube, $1 \mathrm{ml}$ of organic extract was dried under vacuum, after 2 drops of $1 \mathrm{M} \mathrm{HCl}$ had been added, then $1 \mathrm{ml}$ of $0.1 \mathrm{M} \mathrm{HCl}, 0.5 \mu \mathrm{l}$ saturated standard solution of Sodium bicarbonate and I $\mathrm{ml}$ of dansyl Chloride $(5 \mathrm{mg} / \mathrm{ml})$ were added, then incubation at $40{ }^{\circ} \mathrm{C}$ for $1 \mathrm{~h}$ then the solution was dried under vacuum, and the solvents were added followed by HPLC injection.

2.3.4. Chromatographic fractionation:
High performance liquid chromatography used for dansylamines determination was an Agilent 1100 HPLC system, Agilen Technologies, Waldbronn, Germany, equipped with quaternary pump model G 1311A, UV detector (Model G 1314A) set at $254 \mathrm{~nm}$ wavelength and the data were recorded by Software program 2010. The mobile phase consists of solvent A: acetonitrile and solvent $\mathrm{B}$ : water with flow rate $0.8 \mathrm{ml} / \mathrm{min}$.

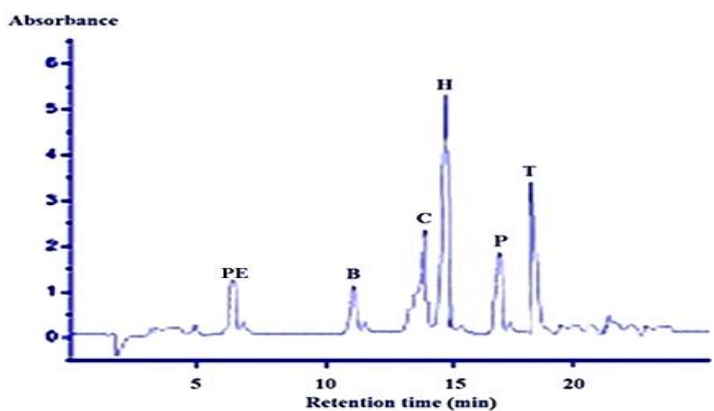

Chromatograms of the areas of biogenic amines standard solutions derivatized by HPLC. PE: Phenylethylamine (RT $=6.5 \mathrm{~min})$. B: Putrescine $(\mathrm{RT}=11.4 \mathrm{~min})$. C: Cadaverine $(\mathrm{RT}=13.9 \mathrm{~min}) . \mathbf{H}$ : Histamine (RT=14.7 min). P: Tryptamine $(\mathrm{RT}=17.1 \mathrm{~min}) . \mathbf{T}$ : Tyramine (RT=18.3 min)

\section{RESULTS}

Results achieved in table (1) declared that the mean values of $\mathrm{pH}$, salt $\%$, moisture $\%$ and acidity $\%$ in Cheddar cheese samples were $5.5 \pm 0.02,1.53 \pm 0.04 \%, 40.45 \pm 0.24 \%$ and $0.84 \pm 0.01 \%$, respectively. In Ras cheese samples the mean values of $\mathrm{pH}$, salt $\%$, moisture $\%$ and acidity $\%$ were $4.79 \pm 0.11,4.42 \pm 0.05 \%, 38.64 \pm 0.34 \%$ and $1.70 \pm 0.04 \%$, respectively.

Table (2) declared that the incidence of BAs in the examined Cheddar and Ras cheese samples were 70 and $80 \%$ for histamine, 80 and $90 \%$ for tyramine, 70 and $80 \%$ for cadaverine, 80 and $80 \%$ for putrescine, 45 and $70 \%$ for tryptamine and ND and $65 \%$ for PEA, respectively with a mean values of $3.34 \pm 0.89$ and $8.28 \pm 1.03 \mathrm{mg} / 100 \mathrm{~g}$ for histamine, $5.29 \pm 0.76$ and $4.32 \pm 0.74 \mathrm{mg} / 100 \mathrm{~g}$ for tyramine, $1.39 \pm 0.66$ and $3.68 \pm 1.46 \mathrm{mg} / 100 \mathrm{~g}$ for cadaverine, $1.94 \pm 0.30$ and $7.44 \pm 0.96 \mathrm{mg} / 100 \mathrm{~g}$ for putrescine, $0.69 \pm 0.11$ and $2.83 \pm 0.28 \mathrm{mg} / 100 \mathrm{~g}$ for tryptamine while ND and $2.40 \pm 0.17 \mathrm{mg} / 100 \mathrm{~g}$ PEA, in the examined samples respectively.

Table 1 Statistical analytical results of $\mathrm{pH}$, salt\%, Moisture\% and Acidity\% in the examined Cheddar and Ras cheese samples (n=20 each).

\begin{tabular}{|c|c|c|c|c|c|c|c|c|}
\hline \multirow[t]{2}{*}{ Cheese type } & \multicolumn{3}{|c|}{$\mathrm{pH}$ value } & \multicolumn{2}{|l|}{ Salt $\%$} & \multicolumn{2}{|l|}{ Moisture\% } & \multirow{2}{*}{$\begin{array}{r}\text { Acidity } \% \\
\text { Mean } \pm \text { SEM }^{*}\end{array}$} \\
\hline & Range & Mean \pm SEM $^{*}$ & Range & Mean $\pm \mathrm{SEM}^{*}$ & Range & Mean \pm SEM $*$ & Range & \\
\hline Cheddar & $5.34-5.75$ & $5.5 \pm 0.02$ & $1.20-1.9$ & $1.53 \pm 0.04$ & $38.70-42.1$ & $40.45 \pm 0.24 \mathrm{~b}$ & $0.69-0.93$ & $0.84 \pm 0.01$ \\
\hline Ras & $3.78-5.45$ & $4.79 \pm 0.11$ & $4.00-4.8$ & $4.42 \pm 0.05$ & $35.90-40.4$ & $38.64 \pm 0.34 \mathrm{a}$ & $1.35-1.93$ & $1.70 \pm 0.04$ \\
\hline
\end{tabular}

Standard error mean. Mean values in the same column with the different letters are significantly different $(\mathrm{P}<0.05)$.

Table 2 Statistical analytical results of BAs mg/100g in examined Cheddar and Ras cheese samples ( $\mathrm{n}=20$ each)

\begin{tabular}{|c|c|c|c|c|c|c|c|c|}
\hline \multirow{3}{*}{ Biogenic amines $\mathrm{mg} / 100 \mathrm{~g}$} & \multicolumn{8}{|c|}{ Cheese types } \\
\hline & \multicolumn{4}{|c|}{ Cheeder cheese } & \multicolumn{4}{|c|}{ Ras cheese } \\
\hline & No. & $\%$ & Range & Mean \pm SEM $^{*}$ & No. & $\%$ & Range & Mean \pm SEM $*$ \\
\hline Histamine & 14 & 70 & $0.20-10.00$ & $3.34 \pm 0.89 b$ & 16 & 80 & $0.60-13.40$ & $8.28 \pm 1.03 a$ \\
\hline Tyramine & 16 & 80 & $1.00-10.02$ & $5.29 \pm 0.76 \mathrm{a}$ & 18 & 90 & $0.20-9.00$ & $4.32 \pm 0.74 \mathrm{a}$ \\
\hline Cadaverine & 14 & 70 & $0.04-10.44$ & $1.39 \pm 0.66 \mathrm{a}$ & 16 & 80 & $00.10-9.08$ & $3.68 \pm 1.46 \mathrm{a}$ \\
\hline Puterscine & 16 & 80 & $0.10-3.51$ & $1.94 \pm 0.30 \mathrm{~b}$ & 16 & 80 & $0.40-11.20$ & $7.44 \pm 0.96 \mathrm{a}$ \\
\hline Tryptamine & 9 & 45 & $0.20-1.23$ & $0.69 \pm 0.11$ & 14 & 70 & $1.60-5.10$ & $2.83 \pm 0.28$ \\
\hline PEA & & & ND* & & 13 & 65 & $1.00-3.00$ & $2.40 \pm 0.17$ \\
\hline
\end{tabular}

Table (3) illustrate the correlation coefficient between $(\mathrm{pH}$, salt $\%$, moisture $\%$ and acidity $\%$ ) and BAs formation in examined cheese samples, in which there was a negative correlation at the 0.05 level between $(\mathrm{pH}$ value and moisture 
content) and BAs production, but there was a positive correlation at the 0.01 level between (salt content and acidity $\%)$ and BAs production. Inspection of table (4) showed that all Cheddar cheese samples were accepted according to maximum permissible limit of BAs in FDA (2001) $(10 \mathrm{mg} / 100 \mathrm{~g})$ and EOS (2007) $(20 \mathrm{mg} / 100 \mathrm{~g})$. On the other hand, all Ras cheese samples are accepted according to EOS (2007) and FDA (2001) except 40, $10 \%$ exceeded the MPL of histamine and putrescine stated by FDA (2001). The acceptable level of tryptamine and PEA in cheese is not available.

Table 3 Correlation between chemical analysis and biogenic amines production in examined hard cheese samples.

\begin{tabular}{|c|c|c|c|c|}
\hline $\begin{array}{l}\text { Biogenic } \\
\text { amines }\end{array}$ & $\mathrm{pH}$ & Salt\% & $\begin{array}{l}\text { Moisture } \\
\%\end{array}$ & $\begin{array}{l}\text { acidity } \\
\%\end{array}$ \\
\hline Histamine & -0.008 & $0.244 *$ & 0.001 & $0.525^{* * *}$ \\
\hline Tyramine & 0.062 & -0.113 & 0.223 & $0.362^{* *}$ \\
\hline $\begin{array}{l}\text { Cadaverin } \\
\mathrm{e}\end{array}$ & 0.131 & -0.084 & -0.102 & -0.157 \\
\hline puterscine & -0.074 & $0.299 *$ & -0.105 & $0.537 * *$ \\
\hline tryptamine & & $\begin{array}{l}0.570^{*} \\
*\end{array}$ & $-0.523 * *$ & 0.140 \\
\hline PEA & & $0.280^{*}$ & $-0.615^{* *}$ & 0.072 \\
\hline
\end{tabular}

**. Correlation is significant at the 0.01 level (2-tailed). ${ }^{*}$ Correlation is significant at the 0.05 level (2-tailed)

Table 4 Comparison of biogenic amines levels in hard cheese samples with International and Egyptian legislation $(\mathrm{n}=20)$.

\begin{tabular}{lllllllll}
\hline \multicolumn{3}{c}{ Accepted samples including negative samples } \\
\hline $\begin{array}{l}\text { *MPL according to FDA (2001) } \\
(10 \mathrm{mg} / 100 \mathrm{~g})\end{array}$ & \multicolumn{5}{c}{$\begin{array}{c}\text { **MPL according to EOS (2007) } \\
(20 \mathrm{mg} / 100 \mathrm{~g})\end{array}$} \\
\cline { 2 - 9 } & \multicolumn{2}{l}{ Cheddar } & Ras & \multicolumn{3}{c}{ Cheddar } & Ras \\
\cline { 2 - 9 } & NO. & $\%$ & NO. & $\%$ & NO. & $\%$ & NO & $\%$ \\
\hline Histamine & 20 & 100 & 12 & 60 & 20 & 100 & 20 & 100 \\
Tyramine & 20 & 100 & 20 & 100 & 20 & 100 & 20 & 100 \\
Cadaverine & 20 & 100 & 20 & 100 & 20 & 100 & 20 & 100 \\
Puterscine & 20 & 100 & 18 & 90 & 20 & 100 & 20 & 100 \\
\hline
\end{tabular}

*Maximum permissible limit according to FDA (Food and Drugs administration).** Maximum permissible limit according to EOS (Egyptian organization of standards).

\section{DISCUSSION}

Several chemical factors as $\mathrm{pH}, \mathrm{NaCl} \%$, moisture $\%$ and acidity $\%$ can influence the decarboxylase activity of microorganism producing BAs during the production and fermentation of dairy products. Biogenic amines formation can be accelerated by an acidic $\mathrm{pH}$ where decarboxylase enzyme become more active with optimum $\mathrm{pH}$ (5.0) which responsible for BAs formation. Moreover, the bacterial growth can increase the level of BAs, by the production of the decarboxylase enzyme (Lazaro et al., 2013). Table (1) showed higher $\mathrm{pH}$ value in the examined Cheddar cheese samples than Ras cheese samples. Lower results were attained by Morad et al. (2017), but higher result was obtained by Dahmash (2019).

Salt has a role in controlling the microbial growth, various enzyme activities in cheese, reducing of cheese moisture content, and physical changes in cheese proteins that can influence cheese texture, flavor and also formation of BAs (Hayaloglu et al., 2002). It is evident from table (1) that the mean value of salt \% in examined Cheddar and Ras cheese samples was nearly similar to the results obtained by Farag (2018). Lower results were obtained by Awad (2018), but higher result was obtained by Khaled (2014).

Retaining moisture in cheese making is very important to obtain desired texture and control flavor development by the beneficial bacteria (Lee et al., 2011). Higher moisture \% was observed in Cheddar cheese samples than Ras cheese samples. Our results were agreed with Farag (2018), but higher result was obtained by Dahmash (2019), and lower result was obtained by Al-Dawlatly (2017).

Mean value of acidity \% in Cheddar cheese samples was lower than Ras cheese samples may be due to storage at refrigerator temperature $\left(4-10{ }^{\circ} \mathrm{C}\right)$ and good manufacturing conditions. Lower result was obtained by El-Mossalami (2003), but higher result was obtained by Khaled (2014).

Biogenic amines estimation is very important due to their high incidence in different cheese types, especially ripened cheeses, and due to their hazard effect on human health. Also, the fact that BAs are produced not only by microbial dairy contaminants of different origins but also by the microbiota which used in the fermentation of dairy products, such as LAB, yeasts, and moulds, prohibits their control by traditional means (EFSA, 2011).

Dietary histamine is detoxified rapidly by mono and diamine oxidases, but high amounts ingested with food resulted in histamine which characterized by an incubation period from a few minutes to hours. The symptoms of histamine poisoning are related to effects on blood vessels and smooth muscles, and include headache, nasal discharge, bronchospasm, tachycardia, hypotension, edema in eyelids, pruritus, flushing and asthma (Maintz and Novak, 2007).

The results recorded in Table (2) showed higher histamine concentrations in the studied Ras cheese samples than Cheddar cheese samples may be due to enzymatic activity of proteases which derived from microorganisms which reflect the bad hygienic condition during production and storage ( Abo El- Makarem and Amr, 2016). Lower results were gained by Joong et al. (2004), but higher results were obtained by Awad (2018). Nearly similar results were obtained by Mohamed (2004). Tyramine is the prevailing BA in the dairy products and is related to BA-mediated dairy borne intoxications specified as "cheese reaction" (Ten Brink et al., 1990). Mean value of tyramine in examined Cheddar cheese samples was higher than Ras cheese samples may be due to production of tyrosine decarboxylase enzyme by many lactic acid bacteria (Bunkova et al., 2010). Higher results were obtained by Amin et al. (2017) and Awad (2018), but lower results were obtained by Mohamed (2004). The presence of cadaverine in fermented dairy products has an indirect hazard to consumers, as they may potentiate the toxicity of tyramine and histamine, by inhibiting the enzymes of detoxification. (Flick et al., 2001). Mean value of cadaverine in Ras cheese samples was higher than Cheddar cheese samples may be due to high lysine decarboxylase activity of some pathogenic Enterobacteriaceae (Marino et al.,2000). Nearly similar results were observed by El-Mossalami (2003), but higher results were obtained by and Ekbal and Amr (2010).

Putrescine may react with $\mathrm{NO}_{2}$ to form carcinogenic nitrosamines, also it considered as spoilage indicators. Putrescine has a role in enhancement of toxic effects of other BAs by inhibition of detoxifying enzymes (Valsamaki et $a l ., 2000)$. Mean value of putrescine in the examined Ras cheese samples was higher than Cheddar cheese samples. Higher results were obtained by Mayer et al. (2010), but lower results were obtained by Mohamed, (2004).

Tryptamine is formed by decarboxylation of its precursor amino acid, tryptophan and found in a broad extend of concentrations in definite meats, cheese, alcoholic drinks and different fermented foods. Once is formed, it is difficult to be destroyed either by pasteurization or cooking. Its risk effects on humans represented by eruption, migraine hypertension and hypotension (Gnog et al., 2014). Mean 
value of tryptamine in the examined Ras cheese samples was higher than Cheddar cheese samples. Lower levels were acquired by Awad (2018), but higher results were obtained by Khaled (2014).

Ingestion of high-level PEA has been related to some symptoms like headache, vertigo and discomfort. Symptoms appear after $30 \mathrm{~min}$ to a few hours and completely ended after 24 h. (EFSA, 2011). In Ras cheese samples the mean value of PEA was $2.40 \pm 0.17 \mathrm{mg} / 100 \mathrm{~g}$. Higher results were obtained by Al-Dawlatly (2017), but not detected in Cheddar samples. Our results agreed with Rodriguez et al. (2014). From the previous results we found that the low level of PEA may be attributed to degradation effect of some lactic acid bacteria on BAs by oxidase enzymes (Tosukhowong, 2011). This high incidence with low quantities of BAs are not considered a health hazard as small amounts of BAs are normally metabolized physiologically to fewer active forms in human gut (Sanh and Senel, 2015). It was noticed in table (3) that there was negative correlation at 0.05 level between $(\mathrm{pH}$ value and moisture content) and BAs production. Identical results were attained by Swelam (2017) and Farag (2018). But there was positive correlation at 0.01 level between (salt content and acidity \%) and BAs production. Our results agreed with results obtained by Swelam (2017) and Farag (2018). So, we conclude that BAs production is considered a protective mechanism of microorganisms against acidic environments. Finally, table (4) compared the level of BAs in examined cheese samples with International and Egyptian standards in which $40 \%$ and $10 \%$ of Ras cheese samples were unfit based on their contents of histamine and putrescine according to Food and Drug Administration limit $(10 \mathrm{mg} / 100 \mathrm{~g})$. As recommendation, the allowable level of BAs according to EOS (2007) should be altered to assembly the standard stipulated by FDA (2001) for obtaining safer product.

\section{CONCULOSIONS}

The assessment of results obtained allow to conclude that the higher BAs levels were found in Ras cheese than Cheddar cheese samples this is may be due to using low quality raw material or bad storage condition during ripening leading to contamination with BAs producing microorganisms. So strict hygienic conditions should be taken from farm until reaching to consumer.

\section{ACKNOWLEDGMENT}

We would like to thank Milk Hygiene Department, Faculty of Veterinary Medicine, Zagazig University and our supervisor in Animal Health Research Institute for their financial and technical support. This work represents a part of the doctoral research by AUTHOR for the ph. D. degree at the Zagazig University.

\section{REFERENCES}

1. Abo El- Makarem, H. S. Amer, A. 2016. Biogenic amine levels during Ras cheese ripening. $3^{\text {rd }}$ International Food Safety Conference, Damanhour Uni., pp: 8-14.

2. Al-Dawlatly, D. A. A. A. 2017. Study of Some Biogenic Amines In Available In Alexandria Markets. Thesis M.Sc. Alex. Univ. High Institute of Public Health. Dep. of Nutrition.

3. Amine, M. T. Abou el Waffa, M. A. and Abou El-Nile, M. O. 2007. Detection of histamine and tyramine in some cheese. Bulletin of High Institution of Public Health. 37: 4.
4. AOAC "Association of Official Analytical Chemists". 2016. Official methods of analysis. $20^{\text {th }}$ Ed.M. Horwitz. w, (Editor), Academic Press, Washington, D.C., USA.

5. Awad, S. K. 2018. Determination of Biogenic Amines by HPLC In Curd Dairy Products Sold at Local Markets. M.Sc. Thesis, Fac. of Vet. Med. Alex. Uni.

6. Bodmer, S., Imark, C. and Kneubühl, M. 1999. Biogenic amines in foods: Histamine and food processing. Inflamm. Res. 48: 296-300.

7. Bunkova, L. F. Bunka, G. Mantlova, A. Cablova, I. and Sedlacek. 2010. The effect of ripening and storage conditions on the distribution of tyramine, putrescine and cadaverine in Edam cheese. Food Microbiol. 27:880-888.

8. Dahmash, M. S. 2019. Histamine producing bacteria and some biogenic amines in Ras cheese. Thesis Ph.D. Fac. of Vet. Med. Alex. Uni.

9. EFSA "European Food Safety Authority". 2011. Scientific Opinion on risk-based control of biogenic amine formation in fermented foods. EFSA J. 9 (10) P: 23-93.

10. Ekbal, M. A. I. and Amr, A.A. 2010. Comparison of BAs levels in different processed cheese varieties with regulatory specifications. World J. of Dairy and Food Sci. 5: 127-133.

11. El-Mossalami, H. H. A. 2003.Proteolytic microorganisms in curd dairy products with special reference to biogenic amines content. Thesis Ph.D. Fac. of Vet. Med. Alex. Uni.

12. EOS "Egyptian Organization for Standardization and Quality Control". 2007. Detection of poisons and control. Report No. 1796.

13. Farag, I. S. A. 2018.Amino acids profile and biogenic amines levels during Egyptian Ras cheese ripening. Thesis M.Sc., Department of Food Hygiene Fac. of Vet. Med.

14. FDA "Food and Drug Administration". 2001. hazards and controls Guidance, 3rd ed. Center of Food Safety and Nutrition, Washington, U.S.A.

15. Fernández, M., del Río B., Linares, D. M., Martín, M. C. and Alvarez, M. A. 2006. Real time polymerase chain reaction for quantitative detection of histamine-producing bacteria: use in cheese production. J. of Dairy Science. 89:3763-3769.

16. Flick, G. J., Gloria M. P., and Douglas, L. 2001. Potential hazards in cold-smoked fish: biogenic amines. J. Food Sci. 66:1088-1099.

17. Gerner, E. W. and Meyskens, F. L. 2004.Polyamines and cancer: old molecules, new understanding. Nature Reviews Cancer. 4:781- 792 .

18. Gnog, X. Q. N. Wang, X. Lin, L. and Li, J. 2014. Ultraperformance convergence chromatography (UPC2) method for the analysis of biogenic amines in fermented foods Food Chem. 162: 172-175.

19. Hayaloglu, A.A. Guven, M. and Fox, P.F. 2002. Microbiological Biochemical and Technological Properties of Turkish White Cheese 'Beyazpeynir'. International Dairy J. 14: 635-648.

20. Joong, S. M., Sang,O. L., Aera, J., Mooha, L. and Yangha, K 2004. Quantitative Analysis of Biogenic Amines in Raw and Processed Foods of Animal Origin on Korean Domestic Market. Asian-Aust. J. Anim. Sci. 17:1764-1768.

21. Kayagil, F. 2006. Effect of traditional starter cultures on quality of cheese. Thesis M. Sc. Department of Biotechnology. Middle East Technical University.

22. Khaled, M. E. 2014. Biogenic amines and microbiological profile of Egyptian cheeses. African J. of Food Sci. 8: 130139.

23. Ladero, V., Linares, D.M., Fernandez, M. and Alvarez, M.A. 2008. Real time quantitative PCR detection of histamine producing lactic acid bacteria in cheese: relation with histamine content. Food Res Int. 41: 1015-1019.

24. Lazaro, C. A., Conte-Junior, C. A., Cunha, F. L., Marsico, E. T., Mano, S. B. and Franco, R. M. 2013. Validation of an HPLC methodology for the identification and quantification of biogenic amines in chicken meat. Food Analysis Methods. 6:1024-1032.

25. Lehane, L. and Olley, J. 2000. Histamine fish poisoning revisited. International J. of Food Microbiology. 58:1-37.

26. Lee, H., Milani, F. X. and Rankin, S. A. 2011.Effects of residual lactose and galactose on cheese moisture 
determination. Abstract to American Dairy Science Association annual meeting, New Orleans, LA.

27. Maintz, L. and Novak, N. 2007. Histamine and histamine intolerance. American J. Clin. Nutrit. 85: 1185-1196.

28. Mayer, H. K. Fiechter, G. and Fischer, E. 2010. A new ultrapressure liquid chromatography method for the determination of biogenic amines in cheese. J. Chromatogr. A. 1217: 32513257.

29. Moinard C., Cynober L. and deBandt J. P. 2005. Polyamines: metabolism and implications in human diseases. Clin. Nutrit. 24:184-197.

30. Mohamed, J. I. I. 2004. Biogenic Amines and their Forming organisms in cheese. Thesis Ph.D. Suez Canal Uni. Fac. of Vet. Med. Dep. of food hygiene and control.

31. Morad A.A.S., Deeb M.M.A and Elkassas M.W. 2017. Determination of Cadaverine and Putrescine in Different Types of Cheese. Global Vetrenaria.;19: 458-464.

32. Moret, S. and Conte, L. S. 1996. High performance liquid chromatographic evaluation of biogenic amines in foods. J. chromatography. 729: 363-369.

33. Novella-Rodriguez, S., Veciana-Nogues, M., IzquierdoPulido, M. and Vidal-Carou, M. 2003. Distribution of biogenic amines and polyamines in cheese. J Food Sci. 68: 750-756
34. ÖNAL, A. 2007. A review: current analytical methods for the determination of biogenic amines in foods. Food Chemistry. 103: 1475-1486.

35. Rodriguez, M. B. R.; Carneiro, C. S.; Feijo, M. B. S.; ConteJunior, C. A. and Mano, S. B. 2014. Bioactive amines: aspects of quality and safety in food. Food and Nutri. Sci. 5: 138-146.

36. Swelam, S. 2017. Profile of biogenic amines and their correlations with chemical constituents and some properties of Egyptian Ras cheese. Indian J. Dairy Sci. 70: 419-495.

37. Ten Brink, B. Damink, C. Joosten, H. M. L. J. and Huisint Veld, J. H. J. 1990. Occurrence and formation of biologically active amines in foods. Int.J. Food Microbiol. 11: 73-84.

38. Tosukhowong, A., W. Visess-anguan, L. Pumpuang, P. Tepkasikul, A. Panya, and R. Valyasevi. 2011. Biogenic amine formation in Nham, a Thai fermented sausage, and the reduction by commercial starter culture, Lacto-bacillus plantarum BCC 9546. Food Chem. 129: 846-853.

39. Valsamaki, K., Michaelidou, A., and Polychroniadou, A. 2000. Biogenic amine production in Feta cheese. Food Chem. 71: 259-266. 